\title{
Systematic Studies on some Middle Eocene Calcareous Nannofossils / Northern Iraq
}

\author{
Ali H. Elewi \\ Remote Sensing Centre \\ University of Mosul
}

(Received 23/6/2011, Accepted 7/5/2012)

\begin{abstract}
ABCTRACT
Twenty-one surface samples from Avanah Formation dating to Middle Eocene cropping out in Dohuk area, northern Iraq, were studied for their nannofossils with light microscope .The study shows that the formation contains a rich and varied assemblage of nannofossils with a significant development of special forms such as Discoasters and Coccolithes. These forms are useful as stratigraphic indicators in Paleogene sediments and as paleoecological indicators of the studied area. One of these samples had being studied by Scanning Electron Microscope to show some of the diagnostic features of the studied species. The study resulted in the recognition of (12) species belong to (10) genera of calcareous nannofossils.

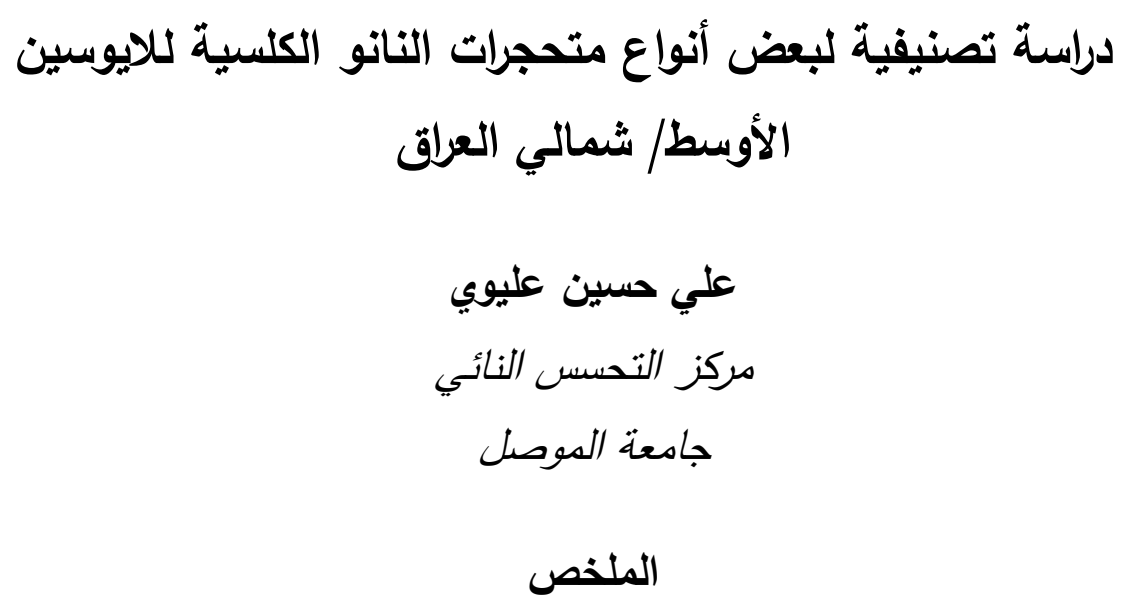

احدى وعشرون عينة صخرية تم اختيارها من المقطع الصخري لتكوين أفانه في الطرف الجنوبي

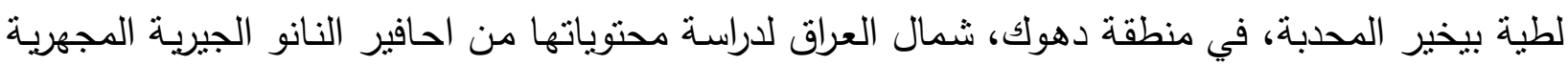

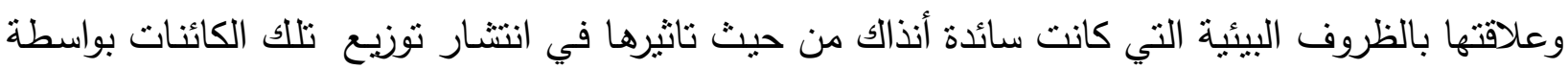
المجر الضوئي، وقد تمت دراسة احدى العينات الاكثر غزارة بمتحجرات النانو بواسطة الدجر الاليكتروني

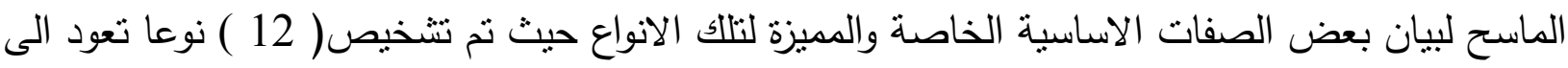
(10) اجناس من متحجرات النانو الكلسية.
\end{abstract}




\section{INTRODUCTION}

In recent years more attention have been paid to the abundant, widely distributed and rapidly evolved calcareous nannofossils. Since the size of these fossils is less than 63 micron, its diagnostic featuers can only be seen under Scanning Electron Microscope which has become more widely available and greatly enhanced the study of nannofossils. Much of the work on the fine structure and formation of these fossils has been made possible by scanning electron microscope.

\section{Material and Method}

Studying calcareous nannofossils, the samples should be properly prepared, because calcareous nannofossils are minute and fragil strong chemicals can not be used. The isolation method which used is based on specific gravity, consisting of three steps:

1- Disperse the samples.

2- Concentrate the samples.

3- Prepare the samples for SEM.

After coating the sample with gold nice image of single calcareous nannofossils may be obtaind. SEM technique used for study calcareous nannofossils being a feasible means and is now actively developed. The present study deals with the nannopaleontology of Eocene samples from Avanah Formation outcrops in Dohuk area, northern Iraq, (Fig. 1).The studied section consist of marl, marlylimestone and limestone alternating beds with thicknes of about (58) m.( Fig. 2).

One of the studied samples (no.9) contain well preserved assemblages of nannofossils as shown by light microscope survey, was studied by SEM. The study is mainly restricted to mention the diagnostic features of some Eocene forms, from the area under investigation. A set of positive prints of the SEM photomicrographs and the films are deposited in the archives of the SEM unit, Physical Department, Faculity of Science, Cairo University -Egypt with serial No. (217-296).

\section{Systematic Paleontology}

The Classification was based on Perch-Nielsen (1985), Young and Bown (1997):

Kingdom: PROTISTA

Division: Chrysophyta Rothmaler, 1949

Class: Coccolithophyceae Rothmaler, 1949

Family: Discoasteraceae Tan Sin Hok, 1927

Genus: Discoaster Tan Sin Hok, 1927

Type species: Discoaster pentaradiatus Tan Sin Hok, 1927 
Discoaster barbadiensis Tan Sin Hok, 1927

Pl. 1, Fig . 2

1927 Discoaser barbadiensis Tan Sin Hok; 30: 415 c.

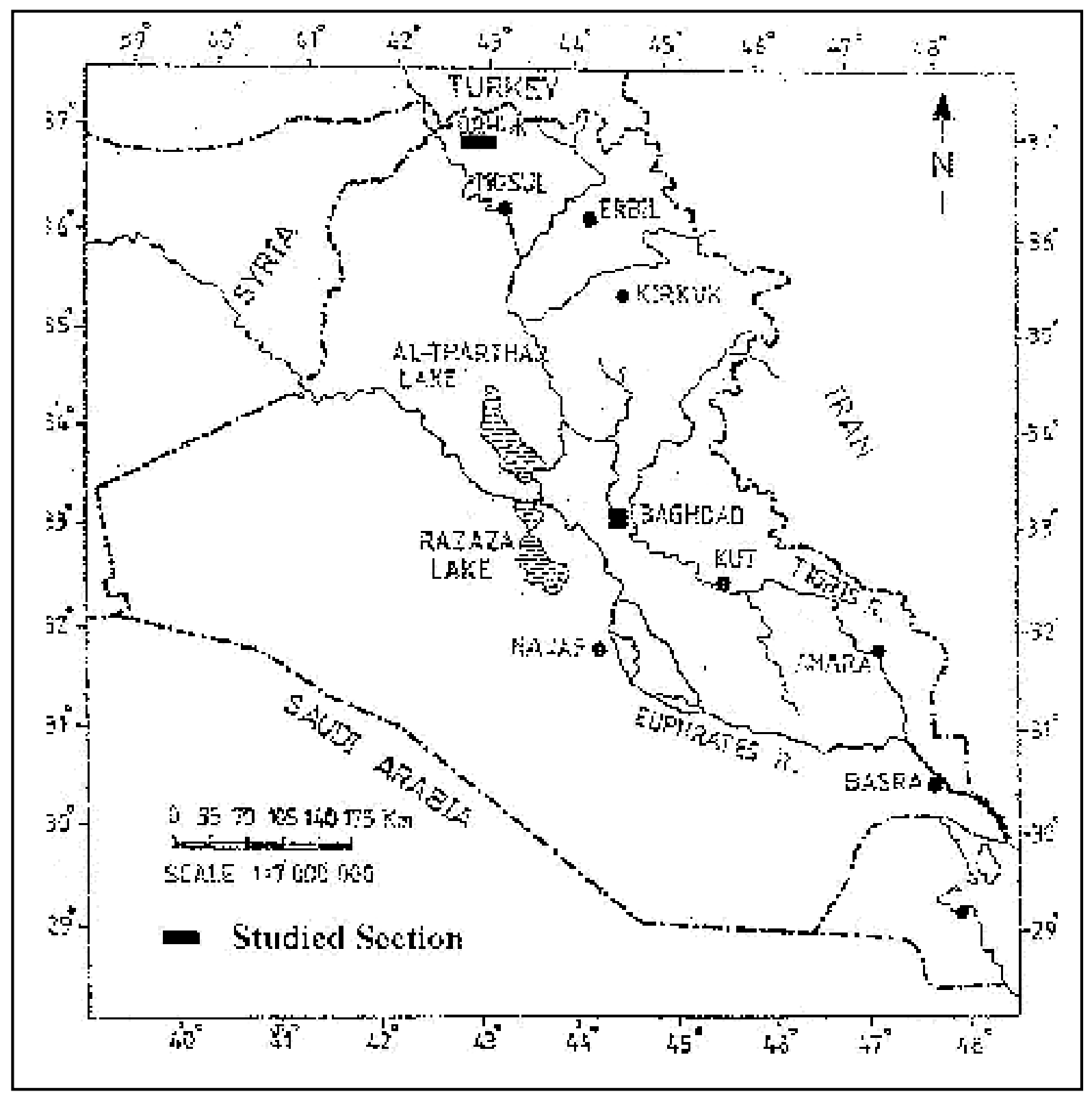

Fig. 1: Location map of the Studied Section. 
Ali H. Elewi

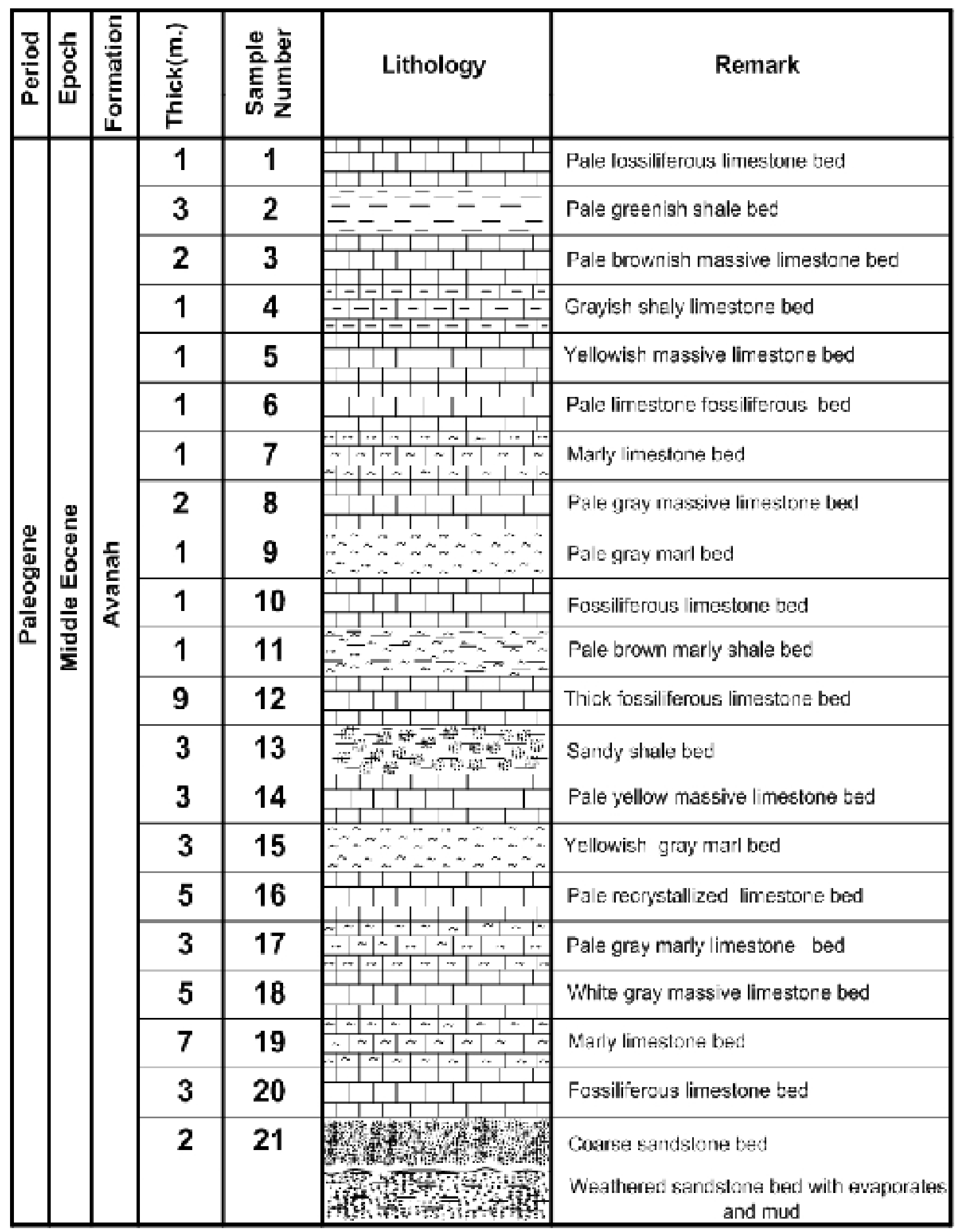

Fig.2: Lithological Section of the Avanah Formation, Dohouk Area. 
1984 Discoaster barbadiensis Tan Sin Hok-El-Dawoody and Elewi; 2 No. 4 , 365 - 382, pl. 2 , Fig. 3

1992 Discoaster barbadiensis Tan Sin Hok-El-Dawoody; 407- 432, pl. 3 Fig. 9.

2011 Discoaster barbadiensis Tan Sin Hok-Al-Badrani; 11, (1), pp. 71 - 84, pl. 1, Fig. 4.

\section{Description:}

A robust asteroliths with (11) pointed rays which are connected for most of their length along straight radial sutures, its diagnostic features show specimens of basket - shaped with a selender stem on one side of the center.

\section{Occurrences:}

This species was recorded throughout middle Eocene of USA Bukry (1975), Egypt Eldawoody (1992), Iraq Al-Badrani (2011).

Discoaster distinctus Martini, 1958

Pl.1, Fig. 3

1958 Discoaster distinctus Martini; 39: 363, pl. 4, Fig. 17

1976 Discoaster distinctus Martini-Haq and Lohmnn; 1: 154, pl. 6, Fig. 6.

1985 Discoaster distinctus Martini - Perch-Nielsen; p. 468, Fig. 27.

\section{Description:}

Asterolith having usually six rays terminating with deep notch, its diagnostic features show the distinct central knob and the well developed node on each side of the ray at terminal ends which give the appearance of bifurcations to the ray.

\section{Occurrences:}

This species was described from the Middle- Late Eoceneof Iraq, Elewi (1982), Eocene of NW Germany, Martini, (1958), Lower and Middle Eocene of USA, Haq and Lohmann, (1976).

Discoaster elegans Bramlette and Sullivan, 1961

$$
\text { Pl. 1, Fig. .1 }
$$

1961 Discoaster elegans Bramlette and Sullivan; 7: 159, pl. 11, Fig. 16 1976 Discoaster elegans Bramlette and Sullivan -Haq and Lohmann; 1: 154, pl. 5, Fig. 3.

1985 Discoaster elegans Bramlette and Sullivan - Perch - Nielsen; p. 468, Fig. 27. 


\section{Description:}

Asterolith rosette-like, consisting of (11) pointed rays or segments of equal size, seems to be very similar to Discoaster barbadiensis, its diagnostic features show specimens with delicate concentric lines or depressions parallel to the periphery.

\section{Occurrences:}

This species was recorded throughout Lower - middle Eocene of Iraq, Elewi (1982), Al-Badrani (2011), Eocene of Egypt,El-Dawoody, (1992).

Family: Prinsiaceae Hay and Mohler, 1967

Genus: Reticulofenestra Hay and Wade (emed.Stradner),1968

Type species: Tremalithus placomorphus Kamptner, 1948 Reticulofenestra umbilica (Levin, 1965) Martini and Ritzkowski, 1968 Pl. 1, Fig. 4

1965 Coccolithus umbilicus Levin; 39: 265, pl. 41, Fig .2

1968 Reticulofenestra umbilica (Levin)- Martini and Ritzkowski; 69: 233 - 7. 1976 Reticulofenestra umbilica (Levin) - Haq and Lohmann; 1: 154, pl. 7, Figs. 7 1985 Reticulofenestra umbilica (Levin)- Perch-Nielsen; p. 506, Figs. 59, 60

1998 Reticulofenestra umbilica (Levin) -El-Dawoody; 42/2, 365 - 392.

\section{Description:}

Large elliptical coccoliths with large central opening spanned on the proximal side by a reticulate membrane consisting of anastomosing rods which are derivatives of the proximal shield, the central part has numerous small circular pores which elongate into slits near the margin.

\section{Occurrences:}

This species was recorded throughout middle Eocene of Egypt (El- Dawoody 1998), U.S.A (Levin 1965) and Iraq (Elewi 1982).

Family: Calyptrosphaeraceae Boudreaux and Hay, 1969

Genus: Daktylethra Gartner, 1969

Type species: Daktylethra punctulata Gartner, 1969

Daktylethra punctulata Gartner, 1969

$$
\text { P1. 1, Fig. } 5
$$

1969 Daktylethra punctulata Gartner (in Gartner and Bukry ); 43, pp. 1213-1221, pls. 139 - 142.

1971b Daktylethra punctulata Gartner -Perch-Neilsen; 18, No. 3, pp. 1-76, pls. 1 - 61, Figs. 1 - 2.

1972 Daktylethra punctulata Gartner - Loker; 3, No. 5, pp.735 - 823, 1985

Daktylethra punctulata Gartner-Perch-Nielsen; p. 453, Fig. 13. 


\section{Description:}

This species has adistinctive helmet-shaped holococcolith with a concave base and an elliptical cross section, the upper half of the helmet has umerous, large, circular pits and spike-like projections.

\section{Occurrences:}

This species was recorded throughout the middle Eocene of Alabama (Blow 1969).

Genus: Zygrhablithus Deflandre, 1959

Type species: Zygolithus bijugatus Deflandre, 1954

Zygrhablithus bijugatus (Deflandre) 1954, Deflandre, 1959

$$
\text { Pl. 2, Fig. } 1
$$

1954 Zygolithus bijugatus Deflandre (in Deflandre and Fert); 40, pp. 115-176, pls. 1 - 15, Figs. 1 - 127.

1959 Zygrhablithus bijugatus (Deflandre)- Deflandre; 2, 135.

1961 Zygrhablithus bijugatus (Deflandre) - Bramlette and Sullivan; 7, pp. 129 - 174, pls. 1 - 14.

1975 Zygrhablithus bijugatus (Deflandre)- Bybell ; 11, No. 4, p.177 - 250, pls.1-24.

1985 Zygrhablithus bijugatus (Deflandre)-Perch-Nielsen; p. 453, Fig. 13.

\section{Description :}

This holococcolith has an upward flaring elliptical base which is surmounted by a complex stem - like feature, this stem is $x$ - shaped where it joins the basal disc, there is a depression in the base between each of the cross bar of the $\mathrm{x}$, the crossbar rise upward as blade like vanes to form the stem.

\section{Occurrences:}

This species occurs throughout the middle Eocene of Alabama (Blow 1969 ).

Family: Pontosphaeraceae Lemmermann, 1908

Genus: Pontosphaera Lohmann, 1902

Type species : Pontosphaera syracusana Lohmann, 1902

Pontosphaera multipora (Kamptner, 1948), Roth 1970

P1. 2, Fig. 2

1948 Discolithus multiporus Kamptner; 157, pp. 1 - 16, 2 pls.

1968 Discolithina multipora (Kamptner) - Haq; 18, pp. 13 - 74, pls. 1- 11, Figs. 3

1970 Pontosphaera multipora (Kamptner)-Roth; 63, p. 860 .

1985 Pontosphaera multipora (Kamptner)- Perch-Nielsen; p. 499, Figs. 51, 53. 


\section{Description:}

This discolith has numerous circular pores of approximately uniform size on its surface arranged in arrows parallel to the periphery, the ridges between the pores give the distal side an irregular, bumpy surface.

\section{Occurrences:}

This species was recorded through middle Eocene of Alabama (Blow 1969).

Family: Rhabdosphaeraceae Lemmermann, 1908

Genus: Blackites Hay and Towe, 1962

Type species: Discolithus spinosus Deflandre and Fert, 1954

Blackites creber (Deflandre), 1954, Bybell, 1975

Pl. 2, Fig. 3

1954 Rhabdolithus creber Deflandre (in Deflandre and Fert); 40, pp. 115-176, pls. 1 - 15, Figs. 1 - 127.

1961 Rhabdosphaera crebra (Deflandre) -Bramlette and Sulivan; 7, pp. 129 - 174, pls. 1 - 14.

1975 Blackites creber (Deflandre) - Bybell; 11, No. 4, pp. 177 - 250, pls. 1-24. 1985.

\section{Description:}

This rhabdolith posses an arched basal plate with four cycles of crystal elements surmounted by a narrow tapering circular stem attached to a basal plate with a more pronounced collar which is distinct and flares out from the stem. Its diagnostic features shows that the collar of $\boldsymbol{B}$. creber has tow aligned layer of crystallites which are all vertically arranged.

\section{Occurrences:}

This species was recorded throughout the middle Eocene of Alabama (Blow 1969).

Family: Sphenolithaceae Deflandre, 1952

Genus: Sphenolithus Deflandre, 1952

Type species: Sphenolithus radians Deflandre, 1952

Sphenolithus radians Deflandre, 1952

Pl. 2, Fig. 5

1952 Sphenolithus radians Deflandre (in Grasse ); 1: 1466, Figs. 343, 363.

1976 Sphenolithus radians Deflandre - Haq and Lohman; 1: 158, pl. 10

Figs. 11, 12 .

1985 Sphenolithus radians Deflandre-Perch-Nielsen; p. 517, Fig. 70.

\section{Description:}

The individuals of this species appear to show the basal disc is concave and the stem consists of wedge - shaped of several radialy arranged plates ,the base is 
constructed of (4)radiating wedge-shaped elements and is surmounted by several (3) blade-like segments that rise to form a non-bifurcating apical spine.

\section{Occurrences:}

This species was recorded throughout middle Eocene of France (Deflandre 1952), USA (Haq and Lohman 1976), Germany (Perch-Nielsen 1985).

Family: Coccolithaceae Poche, 1913

Genus: Ericsonia Black, 1964

Type species: Ericsonia occidentalis Black, 1964

Ericsonia formosa Black, 1964,Haq, 1971

Pl. 2, Fig. 6

1963 Cyclococcolithus formosus Kamptner; 66, 163, pl. 2, Fig. 8, text Fig. 20 .

1964 Ericsonia formosa (Kamptner )- Black; 7, 306, pls. 50 - 53.

1971 Ericsonia formosa (Kamptner)-Haq; 25: 17, pl. 4, Figs. 7, 8.

1985 Ericsonia formosa (Kamptner )-Perch-Nielsen; p. 465, Figs. 23, 24.

1994 Ericsonia formosa (Kamptner) - El-Dawoody and Elewi; 8, pp. 249258. Fig. 5.

\section{Description:}

This species has a circular form with a wide collar and a small central opening. The collar and shield elements are joined distally along a serrate line. In cross- polarized light only the proximal shield is bright, afeature which distingwishs this species from other circular placoliths.

\section{Occurrences:}

This species was originally recorded from the Eocene sediments of Iraq (ElDawoody and Elewi 1994) and throughout the middle Eocene of Alabama, (Blow 1969).

Genus: Campylosphaera Kamptner, 1963

Type species: Campylosphaera bramletti Kamptner, 1963

Campelosphaera dela (Bramlette and Sullivan ), 1961

$$
\text { Pl. } 1 \text {, Fig. } 6
$$

1961 Coccolithites delus Bramlette and Sullivan; 7: 151, pl. 7, Figs. 1, 2

1967 Campelosphaera dela (Bramlette and Sullivan) - Hay and Mohler; 41: 1531, pl. 198, Fig. 14.

1976 Campelosphaera dela (Bramlette and Sullivan) - Haq and Lohmann; 1: 158, pl. 9, Fig. 3.

1985 Campelosphaera dela (Bramlette and Sullivan)- Perch-Nielsen;p. 457, Fig. 20. 


\section{Description:}

This species is characterized by its subrectangular rim outline and a large central area spand by two crossbars, one aligned with long axis and the other aligned with short axis of the shields .The specimen show clearly the strongly inward curved ends of the rim.

\section{Occurrences:}

This species was recorded throughout the middle Eocene of U.S.A (Bramlette and Sullivan 1961), and Iraq (El-Dawoody and Elewi 1994).

Incertae sedis:

Genus: Nannotetrina Achuthan and Stradner, 1969

Type species : Nannotetrina fulgens Stradner, 1960

Nannotetrina fulgens (Stradner ), 1960, Achuthan and Stradner, 1969 Pl. 2, Fig. 4

1960 Nannotetraster fulgens Stradner (in Martini and Stradner); Vol. 76, 268, Figs. 10 - 16 .

1969 Nannotetrina fulgens (Stradner ) - Achuthan and Stradner ; 1, (1967) :7,pl. 5, Figs. 4 - 6

1971 Nannotetrina fulgens (Stradner) - Perch-Nielsen; 18: 66, pl. 55, Figs. 1 - 7 .

1985 Nannotetrina fulgens (Stradner) - Perch-Nielsen ; p. 534, Fig. 89. 1994 Nannotetrina fulgens (Stradner) - El-Dawoody and Elewi; 8:253, Fig.6.

\section{Description:}

This species is characterized by having ( 4 ) straight arms slightly offset at the center with no marginal rim, the arms seems to be very thick deu to the overgrowth, so there are no ultrastructural features could be seen at the inter-arm space.

\section{Occurrences:}

This species was recorded from the middle Eocene of Germany (Stradner, 1960) and Iraq, (El-Dawoody and Elewi, 1994).

\section{Conclusion:}

Calcareous nannofossils can be used to help determine the paleotemperature and current patterns of ancient oceans, following Perch -Nielsen (1985) Sphenolithus species are characteristic of low latitude, open sea and warm waters, where as Pontosphaera species are frequent in hemipelagic sediments, both genera as well as Discoasters are well represented in the studied section.

The presence of shallow water benthonic foraminifera indicates that these sediments were probably deposited in the neritic zone under fluctuating water conditions (Al-Banna and Al-Mutwal 2002 and 2005). The distribution of 
nannofossils along the studied section is not homogenous, in some strata the microfossils are exceedingly diverse with abundant nannofossils, but other levels may show scarce or sparse species of nannofossils. The exact nature of these fluctuations is unknown. The erratic distribution of these species in the studied area seems to be correspond to the change in lithologic constitute which may reveal changes in physical parameters of the environment.

\section{Acknowledgments:}

The auther would like to thank Prof. Dr. Farouk Sonalla Al-Omari Chief Editor of the Iraqi National Journal of Earth Sciences and Dr. Omar Ahmed AlBadrany,Dept. of Earth Sciences College of Sciences,Mosul University for their comments ,suggestions and careful, critical reading of the manuscript .

\section{REFERENCES}

Achuthan, M. V. and Stradner, H. 1969. Calcareous Nannoplankton from The Wemmelian Stratotype. Proc. $1^{\text {st }}$ Internat. Confer. Plankt. Microfos., Geneva, Vol. 1, 1967, pp. 1 - 13, 5 pls.

Al-Badrani, O. A. 2011. Nannobiostratigraphy of Jaddala Formation in Khleisia Well (Kh 12/7) West Iraq. Iraqi National Journal of Earth Sciences, Vol. 11, No. 1, pp. 71 - 84.

Al-Banna, N. Y. and Al-Mutwali, M. M. 2002. Microfacies Evidence for Eocene Sequences Stratigraphy of Jaddala /Avanah Formation, Sinjar Area, Northwest Iraq. Iraqi Journal of Earth Science, Vol. 2, No. 2, pp. 48 - 58.

Al-Banna, N. Y. and Al-Mutwali, M. M. 2005. Microfacies and Depositional Environment of the Interfingring Beds of Avanah Formation from Selected sections, Sinjar anticline, Northwest Iraq. Raf. SCI. Jour., Vol. 16, No. 1, pp. $109-122$.

Black, M. 1964. Cretaceous and Tertiary Coccoliths from Atlantic Seamounts. Paleontology, Vol. 7, pp. 306 - 316 .

Blow, W. H. 1969. Late middle Eocene to Recent Foraminiferal bio - Stratigraphy, In Bronnimann, P. and Renz, H. H. (Eds.),Proc. $1^{\text {st }}$ Internat. Confer. Plankt. Microfos., Geneva, 1967, pp. 11- 14.

Boudreaux, J. E. and Hay, W. W. 1969. Calcareous Nannoplankton and Biostratigraphy of the Late Pliocene- Pleistocene-Recent sediments in the Submarex Cores. Rev. Espanola Micropaleont. Vol. 1, pp. 249 - 292, 10 pls., 1Fig.

Bramlette, M. N. and Sullivan, F. R. 1961. Coccolithophorids and Related Nannoplankton of the Early Tertiary in California, Micropaleont., 7: 159, pl. 11, Fig. 16. 
Bukry, D. 1975. Coccolith and Silicoflagellate Stratigraphy, Northwestern Pacific Ocean, Deep Sea Drilling Project Leg 32, Initial Rep., pp. 677 - 701 .

Bybell, L. M. 1975. Middle Eocene Calcareous Nannofossils at Little Stave Creek, Alabama, Tulane Stud. GEOL. Paleont., Vol. 11, pp. 177 - 247, pl. 1 - 24.

Deflandre, G. (in Grasse) 1952. Classe Des Coccolithophoride's (Coccolithophoridae Lohmann, 1902). Trait. Zool., Paris, 1, pp. 439 - 470, Figs. 339 - 364.

Deflandre, G. 1959. Sur Les Nannofossiles Calcaires et Leur Syste`me`Tique .Rev. Micropaleont., Paris, Vol. 2, pp. 127 - 152, 4 pls.

Deflandre, G. and Fert, C. 1954. Observations Sur les Coccolithophoride's Actuels et Fossiles en Microscopie Ordinaire et Electronique :Ann. Paleontologie, Vol. 40, p. 115 - 176, pls. 1 - 15, Figs. 1 - 127.

El-Dawoody, A. S. and Elewi, A. H. 1984. Discoasters from some Eocene Rocks in Northern Iraq. J. African Earth Sc. 2 , pp. 365 - 382, pls 1 - 5.

El-Dawoody, A. S.1992. Review on the Biostratigraphy of the Late Paleocene /Eocene Succession in Egypt. Geol of the Arab world Cairo Univ. pp. 407 - 432, pl. 1 - 4.

El-Dawoody, A. S. and Elewi, A .H. 1994. Coccoliths from some Eocene rocks in northern Iraq. M. E. R. C. Ain Shams Univ., Earth Sci. Ser., Vol. 8, pp. $249-258$.

El-Dawoody, A. S. 1998. On the Biostratigraphic Significance of Nannofossils in the Paleogene of Egypt. Egyptian Journal of Geology, Vol. 42/2, pp. 365 - 392, 2 pls.

Elewi, A. H. 1982. Stratigraphical and Paleontological Studies on some Eocene Rocks in Northern Iraq. MSc. thesis, Cairo University, 197p.

Gartner, S. and Bukry, D. 1969. Tertiary Holococcoliths: Jour.Paleont- ology, Vol. 43, pp. 1213 - 1221, pls. 139 - 142.

Haq, B. U. 1968. Studies on Upper Eocene Calcareous Nannoplankton from NW Germany: Stockholm Contr. Geol., Vol. 18, pp. 13 - 74, pls. 1 - 11, 3 Figs.

Haq, B.U. 1971. Paleogene Calcareous Nannoflora. Part 1: Paleocene of West Central Perrsia and Upper Paleocene - Eocene of West Pakistan. Stockh. Contr. Geol., Stockholm, Vol. 25, pp. 1 - 56, 14 pls.

Haq, B. U. and Lohmann G. P. 1976. Early Cenozoic calcareous Nannoplankton Biogeography of the Atlantic Ocean. Marine Micropal., Vol. 1, pp. 119 - 194, 14 pls.

Hay, W. W. and Towe, K. M. 1962. Electronmicroscpe Examination of some Coccoliths from Donzacq (France). Eclog. Geol. Helvet., Vol. 55, pp. 497517,10 pls. 
Hay, W. W. nd Mohler, H. P. 1967.Calcareous Nannoplankton from Early Tertiary Rocks at PontLabau, France, and Paleocene-Early Eocene Correlations. J. Paleont., Tulsa/Oklahoma, 41, pp. 1505 - 1541, pls. 196 - 206, 5 Text - Figs.

Kamptner, E., 1948. Coccolithen aus dem Torton des Inneralpinen Wienar Beckens: Sitz.Ber. Osterr. Akad Wiss., Math.-Nat.K1. Abt. 1, Vol. 157, p. 1 - 16, 2 pls.

Kamptner, E. 1963. Coccolithineen - Skelettreste aus Tiefseeabla - gerungen des Pazifischen Ozeans. Ann. Naturh. Mus. Wien, Vol. 66, pp. 139 - 204, 9 pls., 39 Text - Figs.

Lemmermann, E. 1908. Flagellatae, Chlorophyceae, Coccosphaerales und Silicoflagellatae. In: K. Brandt and C.Apstein (eds.), Nordisches Plankton, pp. 1 - 40. Lipsius and Tischer, Kiel and Leipzig.

Levin, H. L. 1965. Cocclithephoridae and Related Microfossils from the Yasoo Formation ( Eocene ) of Mississippy, J, Paleont., Tulsa / Oklahoma, 39, pp. 265 - 272, pls. 41 - 43. Locker, S. 1972.

Locker, S. 1972. Coccolithineen aus dem Palaeogen Mitteleuropas: Palaeontol. Abh., Aet b, Vol. 3, No. 5, pp. 735 - 823.

Lohmann, H. 1902. Die Coccolithophoridae, eine Monographie der Coccolithen bildenden Flagellaten, zugleich ein Beitrag zur Kenntnis des Mittelmeerauftriebs. Arch. Protistenk., Vol. 1, pp. 89 - 165.

Martini, E. 1958. Discoasteridenund verwandte Formation in NM- Deutschen Eozan(Coccolithiphorida).1,Taxonomische Untersuchungen. Senckenbergiana Lethaea, Vol. 39, pp. 353 - 88.

Martini, E. and Ritzkowski, S. 1968. Die Grenze Eozan / Oligozan in der Typus Region des Unteroligozans (Helmstedt-Egeln-Latdorf). Mem. Bur. Rech. Geol. Mineral., 69 ( Colloque sur 1`Eocene,Paris,mai 1968), 233 - 7.

Martini, E. and Stradner, H. 1960. Nannotetraster, eine Stratigraphisch Bedautsame neue Discoasteridengattung. Erdol-Zeitschr., Wien/ Hamburg, Vol. 76, pp. 266 - 270, 19 Figs.

Perch-Nielsen, K. 1971b. Elektronenmikroskopisch Untersuchungen an Coccolithen und verwandten Foremen aus dem Eoza'n von Danemark: K. Danske Vid. Selskab. Biol. Skr., Vol. 18, No. 3, pp. 1 - 76, pls. 1 - 61.

Perch- Nielsen, K. 1985. Cenozoic Calcareous Nannofossils, in Bolli, H. M., Saundes, J. B. and Perch - Nielsen, K. (eds)., Plankton Stratigraphy, Cambridge University Press. Cambridge, pp. 427 - 554.

Poche, F. 1913. Das System der Protozoa .Arch. Protistenk., Vol. 30, pp. 125 - 321.

Roth, P. H., 1970. Oligocene Calcareous Nannoplankton Biostratigraphy. Eclog . Geol. Helvet., Vol. 63, pp. 799 - 881, pls. 1 - 14.

Tan Sin Hok, 1927. Discoasteridae incertae sedis. Proc. Sect .Sc. K. Akad Wet. Amisterdam, Vol. 30, pp. 411 - 419, 14 Figs.

Young, J. R. and Bown, P. R. 1997. Cenozoic Calcareous Nannoplankton Classification .Jour.of Nannoplankton Research, Vol. 19/1, pp. 36 - 47. 


\section{PLATE 1}

Fig.1: Discoaster elegans Bramlette and Sullivan, sample No. 9, $\mathrm{X}=10000$

Fig. 2: Discoaster barbadiensis Tan Sin Hok, sample No. 9, $\mathrm{X}=15000$

Fig. 3: Discoaster distinctus Martini, sample No. 9, $\mathrm{X}=10000$

Fig. 4 :Reticulofenestra umbilica (Levin),sample No. 9, $\mathrm{X}=5000$

Fig. 5 :Daktylethera punctulata Gartner, sample No.9, $X=8500$

Fig. 6: Campylosphaera dela (Bramlette and Sullivan), sample No. 9, $\mathrm{X}=10000$

\section{PLATE 2}

Fig. 1: Zygrhablithus bijugatus (Deflandre), sample No. 9, $X=8500$

Fig.2 : Pontosphaera multipora (Kamptner), sample No. 9, $\mathrm{X}=5000$

Fig. 3: Blackites creber (Deflandre), sample No. 9, $X=15500$

Fig.4: Nannotetrina fulgens (Stradner), sample No. 9, $\mathrm{X}=25000$

Fig. 5: Sphenolithus radians Deflandre, sample No. 9, $\mathrm{X}=10000$

Fig 6: Ericsonia formosa (Kamptner), sample No. 9, $\mathrm{X}=8500$ 
Systematic Studies on some Middle Eocene Calcareous.............

\section{PLATE 1}

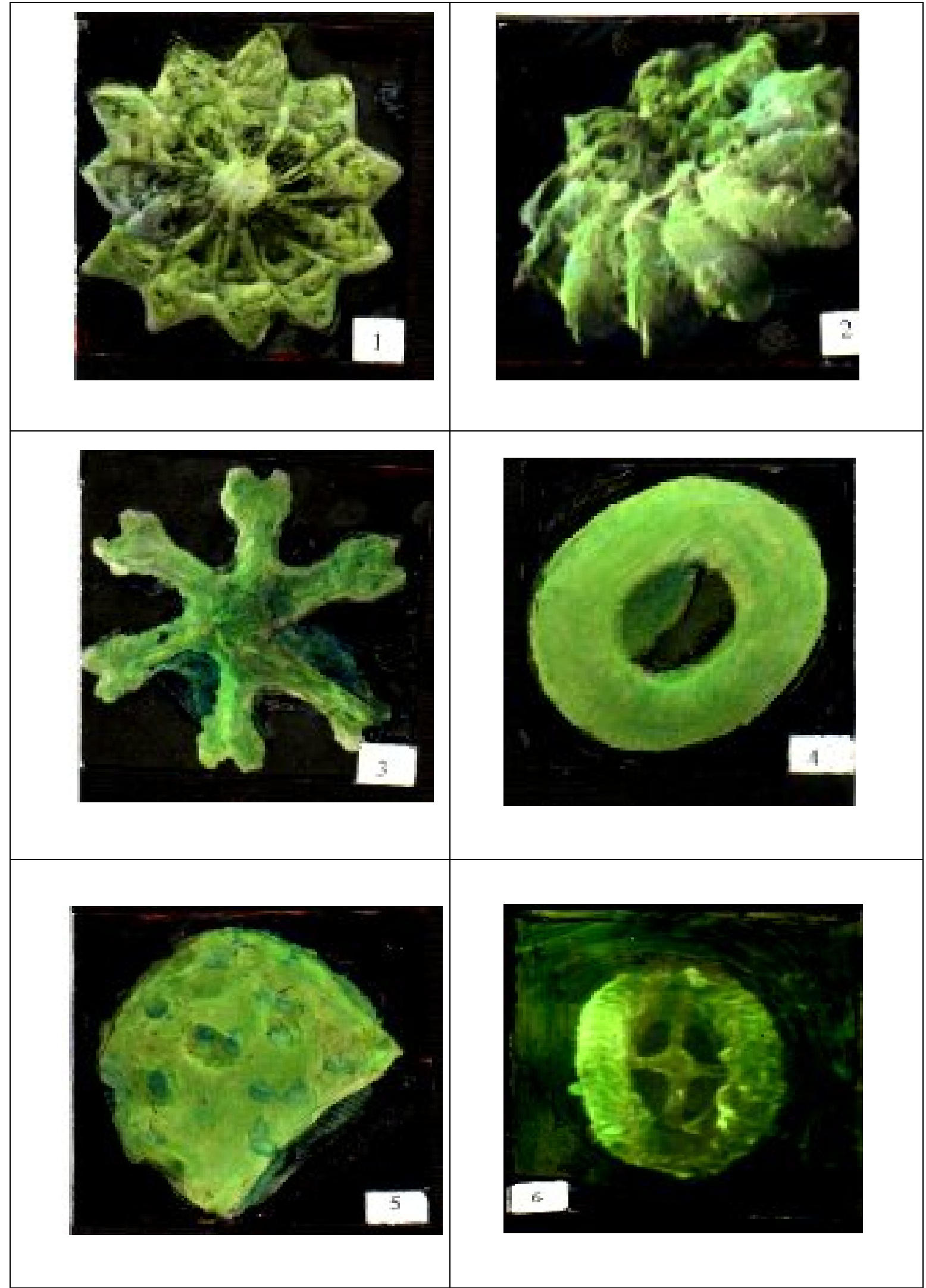


Ali H. Elewi

PLATE 2

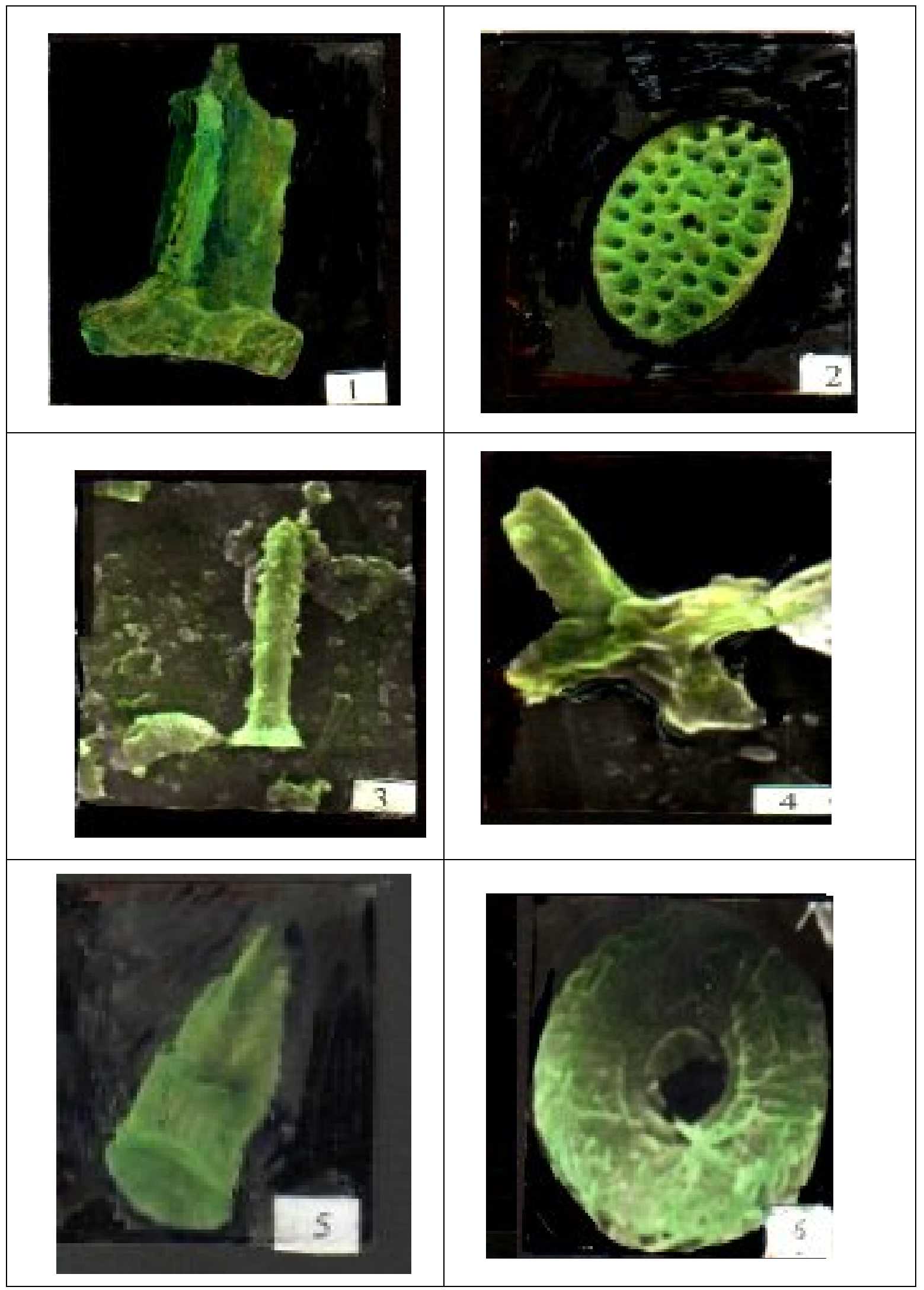

